Int.J. Hum. Soc. Dev. Res.

ISSN (P):2521-1439; ISSN (E):2523-4331

Volume 1, Number 2, 2017.15-27

DOI:10.30546/2523-4331.2017.1.2.15

\title{
INVESTIGATING THE FACTOR OF ENGLISH \\ LANGUAGE ANXIETY IN SPEAKING AMONG THE STUDENTS OF BUITEMS, QUETTA, PAKISTAN
}

\section{Mehwish NAUDHANI}

Baluchistan University of Information Technology, Pakistan Nanjing

University of Science and Technology, China

\author{
Abeera JAMIL \\ Baluchistan University of Information Technology, Pakistan \\ Sehrish NAUDHANI \\ Fatima Jinnah Women's University, Pakistan
}

(C) The Author(s) 2017

\begin{abstract}
The English language being the official language of Pakistan is taught in every educational institute of Pakistan. Keeping in view the importance of English in the country everyone is trying his/her level best to learn English, especially focusing on speaking skills. A significant number of learners feel foreign language anxiety while speaking in the classroom. The study aimed to measure foreign language anxiety among undergraduate students of Baluchistan University of Information Technology, Engineering and Management Sciences (BUITEMS), Pakistan. In order to collect data mixed method was adopted i.e. qualitative and quantitative. The collection of quantitative research data was carried out on 50 undergraduate students through Foreign Language Anxiety Scale by Horwitz et al. (1986), whereas qualitative research data via interviews consists of 5 students from various departments of the university. Through detailed data analysis, it was found that most of the students experience language anxiety when they speak in English because of their self-related problems such as linguistic difficulties (vocabulary, grammar, and pronunciation).
\end{abstract}

(C)2017.All rights reserved

\section{ARTICLE HISTORY}

Received: 11/02/2017

Accepted: 09/07/2017

Published online: 05/10/2017

\section{KEYWORDS}

Foreign language learning, speaking anxiety, undergraduate students.

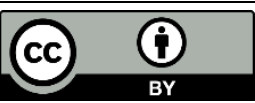

www.ijhsdr.com 


\section{Introduction}

Anxiety or nervousness has consistently been the region of significant interest in language learning process since it is a noteworthy obstruction to foreign language learning that learners need to overcome (Wu, 2010; Zheng, 2008). Anxiety is a complex and multidimensional phenomenon (Young, 1991), it can be defined as - a natural feeling of tension, apprehension, nervousness and worry related to an arousal of the automatic nervous systemll (MacIntyre \& Gardner, 1994).

Early studies have shown that -Anxiety can be associated with feelings of uneasiness, frustration, self-doubt, insecurity or apprehension is intricately intertwined with self-esteem issues and natural ego-preserving fear\| (Zhanibek, 2001). Anxiety happens when learners doubt in their abilities and feel nervous in performing different tasks. MacIntyre and Gardner (1991) suggested that fear of negative evaluation and communication apprehension both are the key factors of learning a foreign language. Speech anxiety or communication anxiety is the fear that an individual feels in class while speaking (Zhanibek 2001).

Hashemi and Abbasi (2013) asserts that anxiety averts productive performance of language learners while learning the target language. -Language anxiety can make learners get discouraged, lose faith in their abilities, escape from participating in classroom activities, and even give up the effort to learn a language welll $(\mathrm{Na}, 2007)$. Consequently, it is imperative that anxiety is a kind of fear that gives negative feelings to a learner who tries to learn a language in class. Subsequently, language anxiety has been the theme of intrigue and research in recent years (Ellis, 2008).

\section{Causes of language anxiety}

Causes of language anxiety are -learner-induced, classroomrelated, skill-specific, and some society-imposed depending on different contexts\| (Zhang and Zhong, 2012). - The main cause of anxiety is -learner's unrealistic or erroneous beliefs about language learning\| (Zhang and Zhong, 2012). Learners made language standards in which they 
had expectations and erroneous beliefs. Videos, tapes and instructors are useful ads for foreign language learners if they want to learn a language of native speakers (Kitano, 2001). Language learners always try to follow the level of native speakers that results in anxiety because they were neglected to accomplish the exclusive requirements (Zhang and Zhong, 2012). In other words, elevated requirements that learners are expected to convey/talk easily out in the open cause anxiety. Language learners dependably imagine that their language abilities particularly speaking abilities are weaker than their companion (Young, 1991). Speaking skill is the main thing that learners dependably contrast with their companions, instructors and local speakers (Kitano, 2001).

Hashemi and Abbasi (2013) considered that casual language classroom condition and friendly environment can control the anxiety. According to them, formal language classroom is the main reason of stress and anxiety because formal language classroom demands correct and clear communication in the target language.Criticism and evaluation of the compeers can also cause anxiety (Conway, 2007). Learners feel fear and anxiety because of awkward and foolish appearance in front of their peers (Jones, 2004). Classroom activities can also cause anxiety especially students feel anxious while commenting errors in pronunciation in front of their classmates. Additionally, oral presentations are most uneasiness inciting classroom activity in which the conditions became strict and tense for the students (Koch and Terrell, 1991).

Horwitz et al. (1986) proposed a literature that situation-specific anxiety which is named as Foreign Language Anxiety is in charge of negative emotional responses to language learning. Adults perceive themselves intelligent in every environment. It is not difficult to communicate with others in native language but communication in a second language is very difficult. Since composite and non-unconstrained mental actions are required with a specific end goal to impart, any execution in L2 is a challenge for understudies because they have fear, feel panic (Horwitz et al. 1986). Studies applying the FLCAS and different measures of second language anxiety found a negative relationship amongst the FLCAS and measures of second language anxiety achievement. 
BUITEMS is an engineering university, where all the engineering courses are offered in the English language. Along with engineering courses, students have to study two English language courses to comprehend spoken and written English, to polish their communication skills and to successfully learn the courses being taught in a foreign language.

The study intended to observe causes of foreign language anxiety in speaking among the undergraduate students of BUITEMS. Therefore to fulfil the purpose of study a mixed-methods approach was adopted, relating both quantitative (questionnaire) and qualitative (open-ended questions in the semi-structured interviews). -Foreign Language Classroom Anxiety Scalell (FLCAS), developed by Horwitz et al. (1986) was used in order to collect quantitative data. The following questions were addressed for semi-structured interviews:

- What are your views about foreign language anxiety in speaking?

- Why do students feel nerves while speaking in front of other students in the class? class?

- Do you compare your English level with other students in the

- Are you afraid that different understudies will laugh at you when you will talk in a foreign language?

- Do you think that other pupils are better than you?

\section{Methodology Research design}

Mixed method research is a methodology for conducting research that involves collecting, analysing, and integrating quantitative and qualitative data in a single study or a longitudinal program of inquiry (Creswell et al. 2003). The researcher adopted a mixed-methods approach, linking both qualitative (open-ended questions in the semi-structured interviews) and quantitative (questionnaire). -Foreign Language Classroom Anxiety Scalel (FLCAS), developed by Horwitz et al. (1986) was used in order to collect quantitative data. 


\section{Sampling}

Participants $(\mathrm{N}=50)$ studying in various departments at BUITEMS were selected in order to collect quantitative data and participants $(\mathrm{N}=5)$ were selected to collect qualitative data. This survey is based on random sampling to make up the sample.

\section{Instrumentation}

Research tools were questionnaires and interviews. Data was collected while using - foreign language classroom anxiety scale- (FLCAS) developed by Hoewitz et al. (1986). The instrument is future to measure factors of foreign language anxiety among the students while speaking in the classroom. The FLCAS is composed of a 5-point Likert scale with 33 statements, extending from strongly agree to strongly disagree. Strongly agree indicates the high level of foreign language anxiety and strongly disagree shows the low level of foreign language anxiety that learners feel in the classroom (Horwitz, 2008). The survey interview is used in qualitative data. A total number of the respondents were 5 from various departments of BUITEMS. Semi-structured interviews with open-ended questions, extending 8 to 10 minutes, were conducted face to face with the participants. Interviews were recorded and transcribed.

\section{Data Analysis}

The quantitative data were analysed by calculating percentages. While qualitative data were analysed according to Horwitz, Horwitz and Cope's theory of foreign language anxiety. The interviews were analysed by keeping in mind different themes from Horwitz, Horwitz and Cope's theory; such as communicating apprehension, test anxiety, fear of negative evaluation, facilitating anxiety and debilitating anxiety. 


\section{Table 1. The calculated percentage of quantitative data:}

\begin{tabular}{|c|c|c|c|c|c|c|c|}
\hline $\begin{array}{l}\mathrm{S} / \\
\mathrm{N}\end{array}$ & Statements & $*$ S.A & A & $\mathrm{N}$ & $\mathrm{D}$ & S.D & $\begin{array}{c}\text { Total } \\
\%\end{array}$ \\
\hline \multirow[t]{2}{*}{1.} & I never feel quite sure of myself when I & $4 \%$ & $46 \%$ & $26 \%$ & $16 \%$ & $8 \%$ & $\begin{array}{c}100 \\
\%\end{array}$ \\
\hline & $\begin{array}{l}\text { am speaking in my foreign language } \\
\text { class. }\end{array}$ & & & & & & \\
\hline \multirow[t]{2}{*}{2.} & I don't worry about making mistakes in & $12 \%$ & $10 \%$ & $6 \%$ & $12 \%$ & $60 \%$ & $\begin{array}{c}100 \\
\%\end{array}$ \\
\hline & a language class. & & & & & & \\
\hline \multirow[t]{2}{*}{3.} & I tremble when I know that I'm going to & $6 \%$ & $46 \%$ & $6 \%$ & $26 \%$ & $16 \%$ & $\begin{array}{c}100 \\
\%\end{array}$ \\
\hline & be called on in the language class. & & & & & & \\
\hline \multirow[t]{2}{*}{4.} & It frightens me when I don't understand & $32 \%$ & $26 \%$ & $12 \%$ & $18 \%$ & $12 \%$ & $\begin{array}{c}100 \\
\% \\
\end{array}$ \\
\hline & $\begin{array}{l}\text { what the teacher is saying in the foreign } \\
\text { language. }\end{array}$ & & & & & & \\
\hline
\end{tabular}

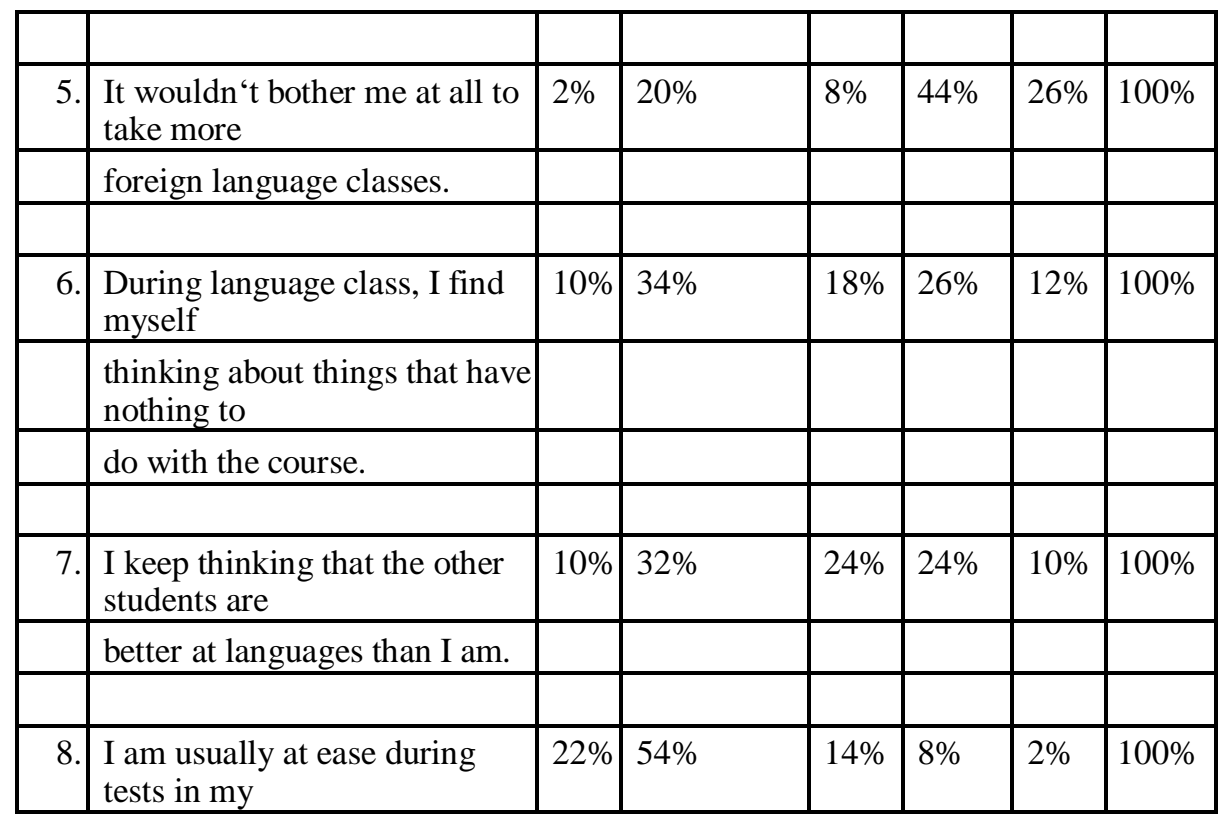

Int.J. Hum. Soc. Dev. Res.

Volume 1, № 2, 2017.15-27 


\begin{tabular}{|c|c|c|c|c|c|c|c|c|}
\hline & language class. & & & & & & & \\
\hline \multirow[t]{2}{*}{9 . } & $\begin{array}{l}\text { I start to panic when I have to } \\
\text { speak }\end{array}$ & $26 \%$ & \multicolumn{2}{|l|}{$4 \%$} & $10 \%$ & $24 \%$ & $6 \%$ & $100 \%$ \\
\hline & $\begin{array}{l}\text { without preparation in a } \\
\text { language class. }\end{array}$ & & & & & & & \\
\hline & & & & & & & & \\
\hline \multirow[t]{2}{*}{10} & $\begin{array}{l}\text { I worry about the } \\
\text { consequences of failing }\end{array}$ & $4 \%$ & \multicolumn{2}{|l|}{$38 \%$} & $20 \%$ & $30 \%$ & $8 \%$ & $100 \%$ \\
\hline & my foreign language class. & & & & & & \\
\hline \multirow[t]{2}{*}{$\begin{array}{ll}11 \\
.\end{array}$} & $\begin{array}{l}\text { I don't understand why some } \\
\text { people get so }\end{array}$ & $16 \%$ & \multicolumn{2}{|l|}{$40 \%$} & $12 \%$ & $26 \%$ & $6 \%$ & $100 \%$ \\
\hline & $\begin{array}{l}\text { upset over foreign language } \\
\text { classes. }\end{array}$ & & & & & & & \\
\hline \multirow[t]{2}{*}{12} & $\begin{array}{l}\text { In language class, I can get so } \\
\text { nervous I }\end{array}$ & $14 \%$ & \multicolumn{2}{|l|}{$32 \%$} & $10 \%$ & $38 \%$ & $6 \%$ & $100 \%$ \\
\hline & forget things I know. & & & & & & & \\
\hline \multirow[t]{2}{*}{13} & $\begin{array}{l}\text { It embarrasses me to volunteer } \\
\text { answers in }\end{array}$ & $8 \%$ & \multicolumn{2}{|l|}{$36 \%$} & $18 \%$ & $30 \%$ & $8 \%$ & $100 \%$ \\
\hline & my language class. & & & & & & & \\
\hline \multirow[t]{2}{*}{14} & $\begin{array}{l}\text { I would not be nervous } \\
\text { speaking the }\end{array}$ & $16 \%$ & \multicolumn{2}{|l|}{$46 \%$} & $10 \%$ & $26 \%$ & $2 \%$ & $100 \%$ \\
\hline & $\begin{array}{l}\text { foreign language with native } \\
\text { speakers. }\end{array}$ & & & & & & \\
\hline \multirow[t]{2}{*}{15} & $\begin{array}{l}\text { I get upset when I don't } \\
\text { understand what }\end{array}$ & $10 \%$ & \multicolumn{2}{|l|}{$20 \%$} & $18 \%$ & $46 \%$ & $6 \%$ & $100 \%$ \\
\hline & the teacher is correcting. & & & & & & & \\
\hline \multirow[t]{2}{*}{16.} & \multicolumn{2}{|l|}{$\begin{array}{l}\text { Even if I am well prepared for a } \\
\text { language }\end{array}$} & $20 \%$ & $32 \%$ & $6 \%$ & $34 \%$ & $8 \%$ & $100 \%$ \\
\hline & \multicolumn{2}{|l|}{ class, I feel anxious about it. } & & & & & & \\
\hline \multirow[t]{2}{*}{17.} & \multicolumn{2}{|l|}{$\begin{array}{l}\text { I often feel like not going to my } \\
\text { language }\end{array}$} & $6 \%$ & $20 \%$ & $14 \%$ & $44 \%$ & $16 \%$ & $100 \%$ \\
\hline & \multicolumn{2}{|l|}{ class } & & & & & & \\
\hline
\end{tabular}




\begin{tabular}{|l|l|l|l|l|l|l|l|}
\hline & & & & & & & \\
\hline 18. & $\begin{array}{l}\text { I feel confident when I speak in } \\
\text { foreign }\end{array}$ & $20 \%$ & $50 \%$ & $20 \%$ & $8 \%$ & $2 \%$ & $100 \%$ \\
\hline & language class. & & & & & & \\
\hline & & & & & & & \\
\hline 19. & $\begin{array}{l}\text { I am afraid that my language } \\
\text { teacher is }\end{array}$ & $14 \%$ & $30 \%$ & $8 \%$ & $40 \%$ & $8 \%$ & $100 \%$ \\
\hline & $\begin{array}{l}\text { ready to correct every mistake I } \\
\text { make. }\end{array}$ & & & & & & \\
\hline & & & & & & & \\
\hline 20. & $\begin{array}{l}\text { I can feel my heart pounding when } \\
\text { I'm }\end{array}$ & $18 \%$ & $26 \%$ & $10 \%$ & $30 \%$ & $16 \%$ & $100 \%$ \\
\hline & $\begin{array}{l}\text { going to be called on in the } \\
\text { language class. }\end{array}$ & & & & & & \\
\hline & \multicolumn{1}{|l|}{} & & & & & & \\
\hline 21. & $\begin{array}{l}\text { The more I study for a language } \\
\text { test, the }\end{array}$ & $16 \%$ & $24 \%$ & $0 \%$ & $46 \%$ & $14 \%$ & $100 \%$ \\
\hline & more confused I get. & & & & & & \\
\hline & & & & & & & \\
\hline 22. & $\begin{array}{l}\text { I don't feel pressure to prepare very } \\
\text { well }\end{array}$ & $12 \%$ & $48 \%$ & $6 \%$ & $26 \%$ & $8 \%$ & $100 \%$ \\
\hline & for a language class. & & & & & & \\
\hline & & & & & & & \\
\hline 23. & $\begin{array}{l}\text { I always feel that the other students } \\
\text { speak }\end{array}$ & $8 \%$ & $34 \%$ & $28 \%$ & $24 \%$ & $6 \%$ & $100 \%$ \\
\hline & $\begin{array}{l}\text { the foreign language better than I } \\
\text { do. }\end{array}$ & & & & & & \\
\hline & & & & & & & \\
\hline 24. & I feel very self-conscious about speaking & $14 \%$ & $36 \%$ & $14 \%$ & $32 \%$ & $4 \%$ & $100 \%$ \\
\hline & $\begin{array}{l}\text { the foreign language in front of } \\
\text { other students. }\end{array}$ & & & & & & \\
\hline & & & & & & & \\
\hline & & & & & & \\
\hline 25. & $\begin{array}{l}\text { Language class moves so quickly I } \\
\text { worry about getting left behind. }\end{array}$ & $16 \%$ & $24 \%$ & $10 \%$ & $40 \%$ & $10 \%$ & $100 \%$ \\
\hline & & & & & & & \\
\hline & & & & & & \\
\hline 26. & I feel more tense and nervous in my & $14 \%$ & $20 \%$ & $14 \%$ & $40 \%$ & $12 \%$ & $100 \%$ \\
\hline & $\begin{array}{l}\text { language class than in my other } \\
\text { classes. }\end{array}$ & & & & & \\
\hline
\end{tabular}




\begin{tabular}{|l|l|l|l|l|l|l|l|}
\hline & & & & & & & \\
\hline 27. & $\begin{array}{l}\text { I get nervous and confused when I } \\
\text { am }\end{array}$ & $18 \%$ & $38 \%$ & $20 \%$ & $20 \%$ & $4 \%$ & $100 \%$ \\
\hline & speaking in my language class. & & & & & & \\
\hline & & & & & & & \\
\hline 28. & $\begin{array}{l}\text { When I'm on my way to language } \\
\text { class, I feel very sure and relaxed. }\end{array}$ & $12 \%$ & $28 \%$ & $18 \%$ & $24 \%$ & $18 \%$ & $100 \%$ \\
\hline
\end{tabular}

*S.A - Strongly Agree, A - Agree, N - Neutral, D - Disagree, S.D - Strongly Disagree. Results

\section{Results drawn from quantitative data are summarised below}

The results in the table below show that when many English as a foreign language (EFL) students go to attend their mainstream classes, their English language anxiety level increases. Students stated that it make them afraid when learners don't comprehend the teacher's instructions in the language class and they get upset. Learners become nervous and start trembling when they are called to speak without preparation. Among the key factors of language anxiety, fear of classmates is noteworthy, students think that their classmates can communicate in a foreign language well than they do and pupils will laugh at them. But few of them were of the view that they don't worry about making mistakes inside the language classroom and they are not at all afraid of attending more language classes and are habitual of taking tests in the language class. They asserted that they sense stress-free when they go to attend language class.

Furthermore, the findings reveal that learners feel confused and nerves while speaking in foreign language class. They illustrated that they become speechless by a number of procedures they have to absorb in order to communicate a foreign language that makes them more nervous and tense in language class as compared to other classes. They often feel like not going to their language class.

\section{Results drawn from qualitative data are summarised below}

- Respondents agreed that language anxiety is a kind communicative apprehension where students face tension, stress, pressure, 
frustration, burden, hesitation, nervousness, uncomfortable, and unconsciousness.

- $80 \%$ students viewed that they feel test anxiety and become blank while speaking in front of the class, whereas $20 \%$ disagreed and said that they are acquainted with each other, spend most of the time together that's why they don't feel hesitation in front of their classmates.

- $100 \%$ learners asserted that class participation is better because it increases the confidence level of students and they can acquire good command in the English language. Relax environment in the classroom plays a vital role in releasing the anxiety.

Debilitating anxiety encourages the learner to -fleell the innovative learning task; the learner emotionally adopts avoidance behaviour (Scovel, 1978; Khattak et al. 2011).

- Some interviewees concluded that facilitating anxiety makes learners motivated to study hard. Students encourage themselves to fight with their weaknesses. Facilitating anxiety motivates the student to -fightl the fresh learning task; it motivates the learner for approach behaviour (Scovel, 1978).

- According to Elaldi (2016), Language anxiety is the dread of negative social assessment which emerges from learner's need in order to make a positive impact on others. $60 \%$ respondents stated that they compare themselves with others in class especially compare with their English level, fluency, vocabulary and sentences and if their weaknesses are exposed, other students will laugh at them. But $40 \%$ disagreed, they think the fear of negative evaluation does not result in language anxiety.

\section{Discussion}

English language anxiety plays a negative role among the undergraduate students of BUITEMS. Poor command of English language makes learners nervous. The above findings show that strict and formal classroom condition can be one of the principle purposes behind understudy's tension. Learners should be provided with a relaxing environment in the classrooms, encouragement from instructors play an important role in overcoming the communicating apprehension. 
Oral presentations make students more anxious because of the fear of other students in class. Few major factors that cause anxiety in the classroom are lack of vocabularyknowledge, distress of failure, fright of grammatical errors and fear of wrong pronunciation and lack of confidence (Chen, 2015). Students take time to build their ideas and make a correction in the English language. While preparing for a presentation, students need practice their English speaking in order to make presentation well and in this way they can reduce language anxiety. To decrease anxiety level of students, teachers must provide oral presentations assignments. In contrast, students who don't get sufficient time for preparing the oral presentation and are weak in a fluent presentation that causes anxiety.

Students viewed that they feel test anxiety and become blank while speaking in front of the class. Due to language anxiety, students can't perform well even if they know the material. Dread of making faults and hesitation about other students can increase the anxiety level of the learners. Failure of examination is also one of the factors of learner's language anxiety.The findings of this study evidently show that instead of usage of modern teaching methodology, the problem of English language anxiety is must be focused amongst the students of BUITEMS.

However, more study is needed in detail to overcome the language anxiety problem. The results in the research may not be satisfactory to provide student's feelings of foreign language anxiety. The researchers have shown study on only foreign language speaking anxiety only at BIUTEMS, Pakistan.

\section{Conclusion}

Considering the results drawn from analysis via questionnaires and interviews, some factors which have currently been pointed out by the students regarding English language anxiety in speaking among the undergraduate students of BUITEMS are as follows:

- The results of this study clearly indicate that still English language anxiety is found among the undergraduate students of BUITEMS, although all the courses are being taught in English.

- From the data analysis, it is revealed that most of the students experience language anxiety when they are supposed to speak in English 
because of their self-related problems such as linguistic difficulties (grammar, pronunciation and vocabulary).

- Cognitive challenges (fear of exams, fear of failure in communication, fear of failure in front of others, fear of making mistakes, lack of self-esteem,) is a common factor among the students.

- Fear of being mocked by class fellows, comparison to their classmates, and fear of laugh cause English language anxiety more dominant.

- Lack of confidence, over self-consciousness, speaking apprehension are also some of the major factors of Language anxiety.

- The current study indicates that friendly and relaxed environment can overcome the language anxiety. Lower English level of students need to improve their speaking and they should practice their language on a regular basis.

- Learners want something that encourages them in class while speaking so that they can't feel anxious in class during the oral performance.

\section{Recommendations}

Keeping in view the above results of the research, the following recommendations can be drawn in order to facilitate the students and teachers. The significance of the subject of language anxiety amongst the learners should be acknowledged across the country by the English language teachers. Relaxed and friendly classroom environment must be provided to the learners. Teachers should encourage students whenever they commit mistakes in a gentle and non-threatening manner. Student-centered teaching techniques must be adopted in the language classroom.Foreign language anxiety awareness ought to be stirred among the understudies so they turn out to be rationally prepared to face the upcoming circumstance. Particularly educators' instructional meetings about how to reduce the language anxiety ought to be organized for English language teachers in BUITEMS as a rule and around the nation specifically.

\section{Disclosure statement}

No potential conflict of interest was reported by the authors. 


\section{References and notes:}

Chen, Y. (2015). ESL Students' Language Anxiety in IN-Oral Presentation. Thesis, Disser-tations and Capstones, pp, 962.

Conway, J. (2007). Anxiety in second language learning; Causes and solutions. Recuper- ado el, 1.

Creswell, J. W., Plano Clark, V. L., Gutmann, M. L., \& Hanson, W. E. (2003). Advanced mixed methods research designs. Handbook of mixed methods in social and behavioral research, 209-240.

Elald1, S. (2016). Foreign language anxiety of students studying English Language and Literature: A Sample from Turkey. Educational Research and Reviews, 11(6), 219-228.

Ellis, R. (2008). The Study of Second Language Acquisition (2nd ed.). Oxford: Oxford University Press.

Hashemi, M., \& Abbasi, M. (2013). The role of the teacher in alleviating anxiety in lan- guage classes. International Research Journal of Applied and Basic Sciences, 4(3), 640646.Horwitz, E. K., Horwitz, M. B., Cope, J. (1986). Foreign language classroom anxiety. Modern Lang. J. 70(2):125-132.

Hoewitz, E. K. (2008). Becoming a language teacher: A practical guide to second language

learning and teaching. Boston, MA: Ally and Bacon.

Jones, J. F. (2004). A cultural context for language anxiety. English Australia Journal, 21(2), 30.

Khattak, Z. I., Jamshed, T., Ahmad, A., \& Baig, M. N. (2011). An investigation into the causes of English language learning anxiety in students at AWKUM. Procedia-Social and Behavioral Sciences, 15, 1600-1604.

Kitano, K. (2001). Anxiety in the college Japanese language classroom. The Modern Lan- guage Journal, 85(4), 549-566.

Koch, A. S., \& Terrel, T. D. (1991). Affective reactions of foreign language students to Nat- ural Approach activities and teaching techniques. In E. K. Horwitz, \& D. J. Young (Eds.), Language anxiety: From theory and research to classroom implications (pp. 109-126).

MacIntyre, P. D., \& Gardner, C. R. (1994). The Subtle Effects of Language Anxiety on Cognitive Processing in the Second Language (pp. 283-305).

MacIntyre, P. D., \& Gardner, R. C. (1991). Language anxiety: Its relationship to other anxieties and to processing in native and second languages. Language Learning, 41: 85-117.

Na, Z. (2007). A study of high school students' English learning anxiety. The Asian EFL Journal, 9(3), 22-34.

Scovel, T. (1978). The effect of affect on foreign language learning: A review of the anxiety research. Language learning, 28(1), 129-142.

$\mathrm{Wu}, \mathrm{K} . \mathrm{H}$. (2010). The relationship between language learners' ${ }^{6}$ anxiety and learning strate-gy in the CLT classrooms. International Education Studies, 3(1), 174.

Young, D. J. (1991). Creating a Low-Anxiety Classroom Environment: What Does Lan- guage Anxiety Research Suggest?. The modern language journal, 75(4), 426-437.

Zhang, R., \& Zhong, J. (2012). The hindrance of doubt: Causes of language anxiety.

Inter-national Journal of English Linguistics, 2(3), 27.

Zhanibek, A. (2001). The relationship between language anxiety and Students'participa- tion in foreign language classes (Doctoral dissertation, Bilkent University).

Zheng, Y. (2008). Anxiety and second/foreign language learning. Canadian Journal. New Scholars Education. 1(1):1-12.

\section{Contact Information}

E-mail: mehwishnaudhani@yahoo.com 